\title{
Interaction between physical activity and nutrition early in life and their impact on later development
}

\author{
Jana Pařízková, \\ Laboratory of Health Promotion, Ist Medical Faculty, Charles University, Prague, \\ Czech Republic
}

\begin{abstract}
It has been rare to find studies of the influence of nutrition on growth that have incorporated careful measurements of physical activity. This paper reviews interactions between physical activity and nutrition in early life and finds that such interactions have a significant influence on growth and later metabolism.

Young animals are generally characterized by a high level of spontaneous motor activity that contributes to a high rate of energy turnover in early life. Such activity varies greatly between species and individuals and can be increased by reduced (but not extreme) dietary intake especially of protein, with consequent effects on growth rate (slower), body composition (leaner), eventual body size (smaller), lifespan (longer), cardiac resistance to toxic substances (increased) and changes in body lipids. Most studies have been conducted with laboratory rats but the much smaller literature concerning human beings is also reviewed here.

In rats, exercise during pregnancy results in offspring that are smaller and leaner and there are later improvements in cardiac microstructure, cardiac resistance to toxic substances and lower plasma cholesterol and triacylglycerol concentrations.

In industrialized countries in recent years, children's fitness, especially of the cardiorespiratory system has not developed at the same pace as body size, or has deteriorated, whereas average body mass index (BMI) and the overall prevalence of obesity have increased. This is partly accounted for by reduced levels of physical activity but there is some evidence that higher intakes of dietary proteins in early life are also implicated. Much recent research has focused on the influence of nutrition in the prenatal and early postnatal period on later health. This review has also underlined the importance of exercise and its interaction with diet beginning with the pregnant mother and continuing through childhood. Development and wider use of simple but reliable methods for the evaluation of physical activity and fitness in young children is now an important priority.
\end{abstract}

\section{Introduction}

Events early in life have both immediate and long term consequences. For example, nutrition during gestation or during the postnatal period may influence the later rate of growth and ultimate body size. This has been studied both in experimental animals (Widdowson \& 
McCance, 1960, 1963; Widdowson, 1962a,b; McCance \& Widdowson, 1974) and humans (Waterlow et al. 1992; Alberti-Fidanza et al. 1995; Pařízková, 1996a). Some diseases have fetal and infant origins. Thus iron deficiency during pregnancy resulted in an increased placental/birth weight ratio and later development of hypertension in the offspring (Barker, 1990, 1994; Jackson, 1992). Children of mothers with hypertension during pregnancy who also manifested higher erythrocyte potassium concentration during childhood became hypertensive during adolescence (Himmelmann et al. 1994).

Attention has largely been paid to inadequate nutrition (Widdowson \& McCance, 1963; Waterlow et al. 1992), with less to the energy output after birth. This would require accurate measurement of basal metabolic rate and energy output above the basal levels-mainly physical activity, and their mutual relationships and balance. Functional and motor characteristics of the organism and its fitness level as a result of energy balance and turnover immediately after birth and during infancy have rarely been reported.

Numerous studies have shown that food intake influences physical activity and vice versa. Malnourished individuals tend to take little voluntary exercise, and physically active individuals usually have larger appetites. However, large interindividual variation in food intake was always found, even within groups of individuals with very similar physical activities, and so were variations in physical activity in individuals with very similar or identical food intake (see Pařízková, 1977, 1989b).

It was possible to make some of these observations only in experimental animals. Fewer measurements have been made in humans and these mainly immediately or soon after birth. Growth studies in school children and adolescents did not take into account previous nutrition. Moreover, they focused mainly on morphological, psychological, social and nutritional changes. Much less attention has been paid to changes in cardiorespiratory system, gross and fine motor development, functional capacity and physical fitness, body posture and metabolic variables related to specific diets. Preschool children were seldom studied as compared with school children and adolescents in spite of the fact that the earlier age is considered to be one of the important critical periods during which later development could be influenced.

Physical activity which accounts for the greatest part of the energy output above the basal level was shown to be the first mechanism to be spared when intake was reduced (Kraut, 1972). However, spontaneous physical activity under conditions of restricted dietary intake seems not to have been accurately measured. Moreover, most studies involved the influence of extreme malnutrition rather than various degrees of food restriction, as compared with ad lib. intake.

A diet restricted in energy resulted in slower growth, smaller body size, and longer life span in rats. This was associated with a reduced prevalence of chronic diseases at older ages (McCay et al. 1939, 1941). Ross $(1961,1964,1972)$ and Ross et al. (1976) confirmed these findings and showed that the prolongation of life span, with its implications of better health and fitness, applied to animals kept on a moderately restricted diet and growing more slowly, as compared with the animals fed ad lib. Masoro (1992, 1993, 1995, 1996) followed up McCay's work on undernutrition and longevity, with special reference to endocrine and metabolic aspects, but did not examine the changes and influence of physical activity.

Observations in long living humans in Abkhasia and Azerbaijan also indicate that this population has been characterized by slower growth and later sexual maturation. Average values of height, weight and triceps skinfolds were significantly lower in the same age categories in children from these regions than in those of the ethnically close Georgians. These grew faster, but did not live as long (Miklashevskaya, 1994). Breadth measurements of the skeleton did not differ significantly. The results of observations in humans correspond to the conclusions from the experiments of McCay et al., Ross et al. and Masoro et al. referred to 
above. Slower growth, smaller body size and reduced fatness are usually connected with smaller food intake, which was also assumed in rural Abkhasian and Azerbaijani children as compared to Georgian children from larger communities.

This review focuses on the interactions between physical activity and nutrition early in life (especially on protein intake) and their influence on the development of spontaneous motor activity. The effect of induced exercise as well as of hypokinesia is also considered. Morphological, functional, metabolic and biochemical variables before and after birth, and delayed effects later in life, are considered both in experimental animals and humans.

\section{Animal studies}

The influence of nutrition at weaning on the development of spontaneous physical activity, body composition and later cardiac resistance

Rats that were suckled in small and large litters differed in their growth and morphological development (Widdowson \& McCance, 1960, 1963). Similar results were obtained by Paŕizková (1977). Even when these animals were weaned and had later access to the same food ad lib., they still took less, and remained smaller and leaner than those suckled in small litters. However, they developed a significantly higher level of spontaneous physical activity (up to $9000 \mathrm{~m} /$ day in rotation cages) compared with the heavier control animals that had been suckled in small groups $(n=6)$. This indicated an adequate level of functional capacity (see reviews by Pařízková, 1977, 1996a). It may be argued that the rats suckled in large groups might have had to move more to find a nipple, but no studies of this were made.

The smaller, leaner animals suckled in large groups $(n=12)$ developed a significantly higher resistance of the heart to noxious factors (Pařizková \& Faltová, 1970). They showed significantly less cardiac damage and a lower incidence of spontaneous deaths after the administration of isoprenaline (Faltová \& Pařízková, 1970; Faltová et al. 1983, 1985). Significant relationships between body weight and fatness on the one hand and the degree of cardiac damage on the other were found in the adult animals: under the same experimental conditions the heaviest and fattest animals always developed the greatest cardiac damage, and suffered the most frequent spontaneous deaths (Faltová \& Pařízková, 1970; Pařízková, 1977, $1996 a$ ).

\section{Relationships between physical activity, body composition, dietary intake and cardiac resistance at different ages}

An important characteristic of a growing animal is the high level of spontaneous physical activity measured in a rotation drum (Pařízková, 1977) as compared with an adult of the same species. Energy intake and output per unit body weight is at a higher level during growth than later. Growing animals have a higher basal and above basal metabolic rate than adults, and they have a significantly higher level of spontaneous physical activity. The percentage of depot fat is generally lower during growth than later (Pařízková, 1963a,b). Moreover, under the same experimental conditions the cardiosensitivity to isoprenaline is lower during growth (Pařízková \& Faltová, 1970).

Animals adapted to induced dynamic exercise of an aerobic character (daily run on a treadmill) from weaning until maturity had a significantly lower body weight and body fatness 
(Pařizková \& Staňková, 1964) than control and hypokinetic animals (confined in small spaces $8.75 \times 21.25 \times 12 \mathrm{~cm}$, with wire net walls while enabling some sort of direct contact among animals which limited the isolation stress), and were also more resistant to isoprenaline. This difference was most apparent after the longest period of running, i.e. in the oldest animals, 185 and 205 days old (Pařízková \& Faltová, 1970). The result of induced exercise was less apparent in young animals which are spontaneously very active. Hypokinetic growing animals were heavier and fatter than the exercised and control animals of the same age, and they developed the highest degree of cardiac damage after the administration of isoprenaline, which was similar to much older animals (Paŕizková 1977, 1996a).

When allowed to exercise spontaneously in rotation drums, laboratory rats showed marked interindividual variation in their motor activity at all ages. The positive effect of daily running was related to a certain threshold of activity (i.e. intensity and duration/d) and its duration without longer interruptions (see Pařizková \& Faltová, 1970). The same applied to the exercise induced on the treadmill (Faltová \& Pařízková, 1970). Food intake in the exercised animals was always significantly higher than in those not exercised. When spontaneous exercise in rotation drums was interrupted for 3 days, its cardioprotective effect still persisted, but after 2 weeks interruption it disappeared (Faltová et al. 1985).

\section{Early marginal malnutrition and later development of spontaneous physical activity}

Smart (1974) showed that rats from mothers who were undernourished during much of their pregnancy and throughout lactation were more active than controls and Macho et al. (1973) found increased activity of the thyroid gland in rats undernourished early in life.

Rats suckled by mothers on a low $(5 \%)$ protein diet and continuing with the same diet from weaning until the 49th day also had a reduced energy and protein intake (REP animals) and an increased level of spontaneous physical activity, which continued even after a normal laboratory diet was introduced. Under these conditions, animals increased their activity up to 9 $\mathrm{km} / \mathrm{d}$; such a distance on a motor driven tread mill could have been introduced in only a few selected, but never in all, ad lib. fed rats in which at most $1.2-3.6 \mathrm{~km} / \mathrm{d}$ of running could be achieved.

REP animals grew more slowly and were leaner. This ran parallel with higher cardiac resistance to isoprenaline (see below). It is important that the restriction of food intake is not extreme. In Ross's experiments to which reference was made above, a reduction of food intake to approximately $60 \%$ of $a d$ lib. food intake of comparable controls significantly prolonged the life span.

Suzuki et al. (1978) studied genetically hypertensive rats. One group had forced exercise on a treadmill; a second group had free access to rotation cages where the rats could exercise voluntarily ad lib. The first group had increased blood pressure; in the second blood pressure was reduced significantly.

\section{Modifications of lipid metabolism and of cardiac resistance due to changes in dietary intake after birth}

Food intake/100 g body weight was always higher in REP animals. However, food consumed/ $1 \mathrm{~g}$ weight increment from the 50th to the 105 th day after birth was always significantly lower in REP animals as compared with controls. Growth was thus more efficient, especially taking 
into account the energy expended in the significantly increased motor activity in the rotation cages. The concentration of lipids in the liver was significantly higher, and the synthesis of lipids was lower in animals receiving reduced energy and protein which were more active in rotation cages, as compared with control animals (Pařízková \& Petrásek, 1979; Pařízková et al. 1979, 1980).

In another experiment the degree of cardiac necrosis induced by isoprenaline was followed using ${ }^{203} \mathrm{HgCl}$, the penetration of which into the cardiac cells (evaluated as $\mathrm{cpm} / \mathrm{mg}$ heart tissue) indicates the degree of damage (Pařízková et al. 1982). Four subgroups of male rats were compared in this experiment: they received control (C) or REP diets. All lived in normal laboratory cages, and either had access (REP or C active) or no access (REP or C inactive) to rotation cages.

REP active animals were the most active in rotation cages, were the lightest and leanest, and had least cardiac damage after isoprenaline (Fig. 1). The reverse applied to $\mathrm{C}$ inactive animals. The other groups were intermediate. Greater resistance of the heart could also be related to other changes resulting from lower food intake early in life and higher motor activity later, i.e. changes in the microstructure of the heart, or of lipid metabolism (Paŕizková, 1977, $1996 a$ ).

In animals suckled in smaller or larger litters (Pařízková, 1978b) the small animals from the large litters developed a higher level of spontaneous motor activity in the rotation cages. The concentration of lipids in the small intestine of females, biosynthesis of lipids in the small intestine, concentration of fatty acids in the liver and in the small intestine and synthesis of fatty acids in the small intestine were significantly higher in animals of both sexes from large litters. The synthesis of cholesterol in the liver in males, and in the whole body of both sexes, was significantly lower in animals from large litters (Pařízková \& Petrásek, 1978, 1979).

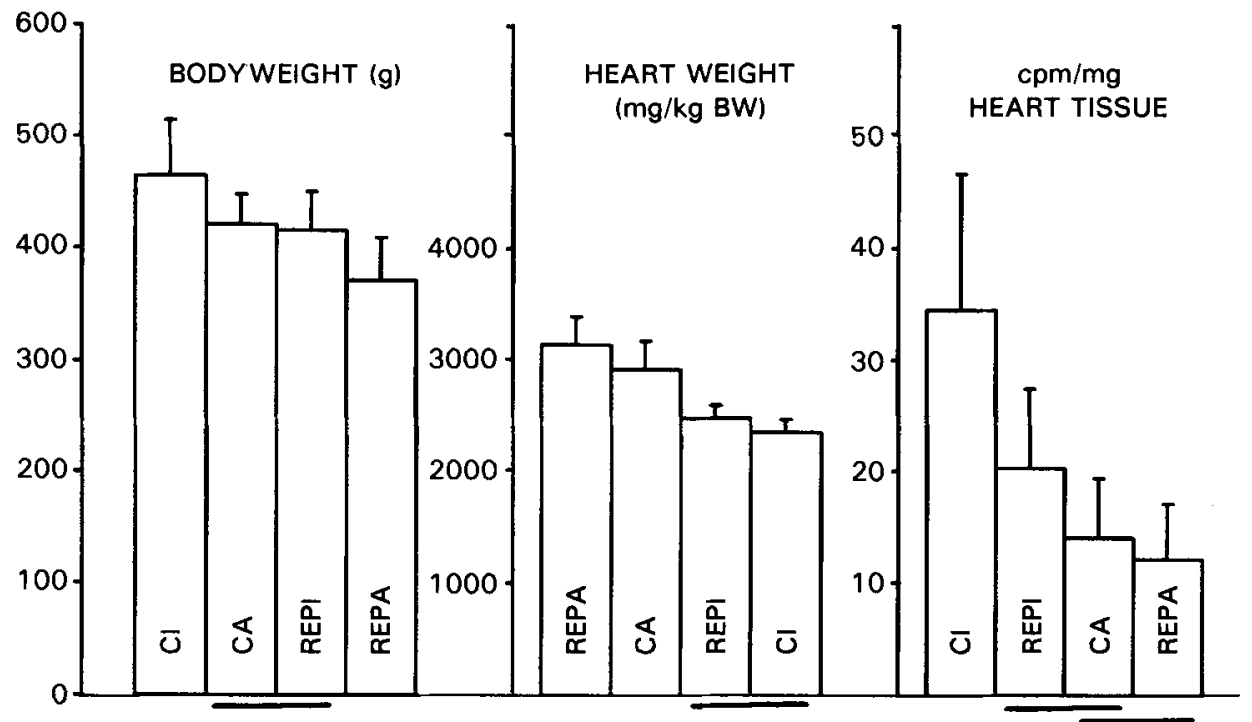

Figure 1. Mean values for body weight, total heart and $\mathrm{cpm} / \mathrm{mg}$ heart tissue (characterizing the degree of cardiac lesion after isoprenaline administration) in male rats with different early nutrition; $\mathrm{CA}$, control, active; $\mathrm{Cl}$, control, inactive; REPA, restricted energy and protein, active; REPI, restricted energy and protein, inactive. Pairs of groups underlined do not differ significantly (Pařizková et al. 1982). 
The influence of physical activity during pregnancy on later development of the offspring

It was not possible to increase motor activity in young animals until after weaning. The influence of the level of physical activity of the mother during pregnancy on the offspring was followed, and later consequences were studied (Pařízková 1978a, 1979, 1989a). Cardiac microstructure, which conditions the level of the functional capacity of the heart and thus of the whole organism, was also analysed. Rats were exercised on a treadmill throughout pregnancy for $1 \mathrm{~h} / \mathrm{d}$, with the speed of $14-16 \mathrm{~m} / \mathrm{min}$, which was a mild aerobic exercise, c. $0.9 \mathrm{~km} / \mathrm{d}$. Compared with the offspring of unexercised controls, the weight of the heart of the offspring of the exercised mothers did not differ significantly at the age of $50 \mathrm{~d}$, but was significantly higher at the age of $100 \mathrm{~d}$. Then greater resistance to isoprenaline was also found (Pařízková, 1978b).

The microstructure of the heart, i.e. the number of capillaries and fibres $/ \mathrm{mm}^{2}$ was significantly higher in the heart muscle of the offspring of the exercised mothers. In addition, the capillary to fibre ratio was significantly higher, and the diffusion distance (i.e. the distance between the centre of the capillary and the centre of a muscle fibre) was significantly shorter in the offspring of exercised rat mothers. This microstructure is favourable from the point of view of the functioning of the heart, especially during a physical work load. Exercise during the postnatal period had a relatively small effect on cardiac microstructure (Pařízková et al. 1972). However, when such exercise was given in addition to the mother's exercise during pregnancy it potentiated the positive effects of the prenatal exercise. While exercise during pregnancy seemed to have the greater effect, changes observed in the exercised offspring of control mothers were significantly greater than in the offspring of control inactive mothers (Pařizková 1975, 1978a, 1979).

The effects of exercise during pregnancy in the rat have also been studied by Piçarro et al. $(1989,1991)$. Weight gain during pregnancy was lower in mothers exercised at different levels of $\mathrm{VO}_{2}$ max. Mothers exercised at $90 \% \dot{\mathrm{VO}}_{2}$ max gave birth to significantly fewer offspring than those with a lower work load. Their birth weight was also lower, but the duration of pregnancy, heart weight of the offspring and $\dot{\mathrm{VO}}_{2} \max$ at 90 days of age were not different. After such a work load during pregnancy there was a significant reduction in fibre/capillary ratio in the heart.

A higher level of activity is also assumed in wild as compared with domesticated rats and/ or rabbits: wild animals have a higher number of capillaries to fibre ratio, shorter diffusion distance etc. (Pařizková et al. 1972). However, it is difficult to compare such differences with those in exercised laboratory rats, as in caught wild animals it is not possible to ascertain their exact age.

Exercise during pregnancy does not change the metabolism in the skeletal muscle of the offspring $28 \mathrm{~d}$ after birth (Rodgers et al. 1991), as indicated by the lack of enzymic changes. Perales et al. (1992) followed the effect of exercise and food restriction in pregnant and newborn rats. In this study, newborn body weight was mainly influenced by food restriction of the mother rather than by her exercise. Weights of brain and heart in the newborn were not affected, but lung and liver weight were significantly reduced by restricted nutrition. Later changes in the offspring were not reported.

Exercised pregnant rats have been found to eat more, gain more weight and have less carcass fat than controls (Courant \& Barr, 1990). At parturition there was also less fat in exercised than in sedentary rats. The same was found in the offspring of the exercised rats during lactation. Litter size and birth weight of the offspring did not differ.

Treadway \& Lederman (1986) followed the effect of swimming until the 19th day of pregnancy $(2 \mathrm{~h} / \mathrm{d}, 5 \mathrm{~d} / \mathrm{week}$, with a $3 \%$ tail weight), and resumed during $2 \mathrm{nd}-14 \mathrm{th}$ day of 
lactation. Food intake was greater in exercised rat mothers during lactation. Milk yields, energy content, protein and fat concentration of maternal milk did not differ, but the milk of exercised rats had a lower lactose concentration. The exercise regimen had no statistically significant effect on litter size or on offspring weight to the 15th day. These results indicate that exercise did not markedly affect the lactational performance of rats fed ad lib.

\section{The effect of exercise during pregnancy on lipid metabolism in the offspring}

Similar experiments to those described above were carried out by Denadai et al. (1994). They confirmed previous findings with regard to weight gain during pregnancy and found that the increase in food intake of exercised pregnant rats was greater during the second week than during other periods of pregnancy. Pregnancy produced an increase in plasma concentration of triacylglycerols and total cholesterol during the 3 rd week of pregnancy, which was lower in the exercised compared to sedentary rats. The fall in the concentration of plasma proteins was also lower at this time in the exercised compared to the sedentary rats. Later changes in the offspring of exercised and sedentary rat mothers were not reported. Szabo et al. (1975) showed that the plasma nonesterified fatty acid concentration has a significant influence on the development of adipose tissue of the fetus.

The concentration of total lipids and fatty acids in the liver was raised in female offspring, and did not differ or was lower in male offspring of exercised mothers at the age of 35 and $90 \mathrm{~d}$. The cholesterol concentration in the liver was increased in both female and male offspring of exercised mothers. In an in vivo study a lower total lipid and fatty acid concentration in the liver of offspring 108 days old was found together with a higher level of serum nonesterified fatty acids. Finally, a higher concentration of cholesterol, higher synthesis of fatty acids and lower cholesterol biosynthesis were found in the small intestine in 100-day old male offspring of exercised mothers compared with those of control mothers (Pařizková \& Petrásek 1978, 1979).

Cobrin \& Koski (1995) showed that acute exercise during pregnancy can have a harmful effect on fetal development only if dietary glucose is severely restricted, but if the maternal diet provided adequate glucose and energy in untrained rat mothers during repeated bouts of acute exercise the fetus was protected.

The swimming of pregnant hares has been shown to increase the number of movements of the fetus in utero. The same result was achieved by the injection of lactic acid into the pregnant hares (Arshavskyi, 1967). From the results of other studies on fetal growth of insulin-like growth factor (Robinson et al. 1995), fasting (Ruwe et al. 1991), diabetes (Honda et al. 1990) and changed umbilical blood flow (Stephenson et al. 1991), it might be deduced that the changes in the levels of nonesterified fatty acids, glucose, lactic acid, hormones etc which occur in the milieu interieur of the pregnant mother during work load and exercise might influence the metabolic situation in the fetus.

\section{Human studies}

The influence of exercise of the mother during pregnancy on the newborn infant

Long term international studies on women who have an intensive work load are difficult to interpret, mainly because they are confounded by economic, social, nutritional and other factors. 
The effect of exercise in pregnant women who continued with endurance training during pregnancy has been followed in their newborn infants. Women adapted to endurance exercise (runners, aerobic dancers) gave birth to children with significantly lower birth weight and birth weight percentile, ponderal index and its percentile, feto-placental weight ratio and skinfold thickness than newborn infants of mothers without exercise training. However, crown-heel length and head circumferences were not affected (Clapp \& Capeless, 1990; Clapp, 1991). Seventy per cent of the difference in birth weight could be explained by the difference in neonatal fat mass, which suggests a modifying effect on lipid metabolism. In runners, the level of exercise performance in the last 5 months of pregnancy explained $40 \%$ of the variation in birth weight over a $1100 \mathrm{~g}$ birth weight range. Other measurements such as serum lipids were not made. A later study of Clapp (1996) confirmed that the offspring of exercised mothers had lower weight and less subcutaneous fat at birth. At the age of five years, the offspring of exercised mothers had the same head circumference and height, and had also lower weight and sum of skinfolds. Motor, integrative and academic readiness skills were similar. However, the offspring of exercised mothers performed better on the Wechsler scales and tests ot oral language skills.

The effects of exercise on the fetus of Canadian women have also been followed (Dale $e t$ al. 1982). The results indicated no significant differences with regard to maternal weight gain and neonatal delivery weight between the group of 33 runners who continued with training during pregnancy and 11 non-runner control subjects. There were fewer quantitative complications of labour and delivery in runners. The second study involved simultaneous electronic monitoring of maternal and fetal heart rate patterns during exercise. A transient fetal bradycardia appeared during a treadmill test which returned to normal during the period of exercise. The differences between the observations on birth weight outcome of Dale et al. (1982), Clapp \& Capeless (1990) and Clapp (1991) may be due to a different intensity of exercise during pregnancy.

Responses of fetal heart rate and uterine contractility to a single bout of moderately strenuous maternal exercise in women at term were studied by Spinnewijn et al. (1996). Fetal heart rate and intrauterine pressure were used for internal monitoring before, during and after maternal exercise at a heart rate of 140 beats/min on a bicycle ergometer. Fetal outcome was good in all cases. Uterine activity increased significantly during the exercise period, both in frequency and in time-pressure integral, compared to a period of rest, with rapid return to base line values after the exercise. This study showed that an exercise bout in healthy pregnant women at term does not cause a change in fetal heart rate pattern suggestive of fetal distress, or a change in fetal behavioural pattern, but it does significantly increase uterine activity. The influence of repeated exercise during the whole pregnancy on the variables studied, or on the status of the newborn, were not reported.

Sternfeld et al. (1995) did not find any significant changes in the fetus due to preconceptional and/or pregnancy exercise. This might be due to the lack of long term observations which concern more variables than those reported up to now. No significantly increased risks or adverse pregnancy outcome were found due to employment during pregnancy, or other daily activities (Hall \& Kaufmann, 1987). Sternfeld et al. (1995) also reported no influence of exercise before conception or during pregnancy on birth weight. The study supports the recently relaxed guidelines for exercise during pregnancy suggested by a number of studies (Uzendoski et al. 1990; Botkin \& Driscoll, 1991; Lookey et al. 1991; Anon. 1994; Schramm et al. 1996; Zhang \& Savitz, 1996). Partly home-based exercise in women with gestational diabetes did not reduce blood glucose levels, but resulted in a modest increase in cardiorespiratory fitness; exercise intervention appeared safe (Avery et al. 1997). 
Cardiac muscle of the fetus seems to be sensitive to the exercise of the mother; Bell \& O'Neill (1994) reported short term increase in heart rate of the fetus due to maternal exercise. Brisk elevation of fetal heart rate after exercise during pregnancy was found in women but there were no signs of distress during labour (Clapp \& Capeless, 1990; Clapp, 1991). This could be considered as one of the causes of the changes in the heart mentioned above (Pařízková, 1978a, 1979).

\section{The influence of nutrition in early life on later development of body mass index and obesity}

Rolland-Cachera et al. $(1984,1988,1995)$ followed longitudinal changes in the development of body mass index (BMI $=\mathrm{kg}$ body weight $/ \mathrm{m}^{2}$ height) as related to dietary intake during growth to adulthood. BMI correlated significantly with total body fat (measured by densitometry, or calculated from skinfold thicknesses) in all age categories (Pařízková, 1989a). BMI increased during the first year after birth, then declined (Rolland-Cachera et al. 1984, 1995); this decline approximated to the time when children started to walk unassisted, and so increased their physical activity and energy output. The decline of BMI lasted on average until 6 years, and then rebounded during later childhood.

The BMI rebound was found to occur at different ages. In some children the BMI increased earlier than 6 years (Rolland-Cachera, 1995) when the level of spontaneous physical activity was still high. But the level of activity decreased at the beginning of school age (Pařizková \& Hainer, 1990). The earlier the BMI rebound, i.e. before 5.5 years of age, the greater the possibility that the child will become obese as an adolescent and/or adult (Rolland-Cachera $e t$ al. 1984, 1988).

In a longitudinal study of nutrition and growth Rolland-Cachera (1995) showed that a higher intake of proteins at two years of age can predispose to the development of obesity later. Changes in BMI were compared when the composition of the diet was high, medium or low in percentages of protein, fat and carbohydrate. At no age was there a difference in total energy intake between these three groups. Only protein was negatively correlated with BMI rebound, i.e. the higher the protein content of the diet at the age of 2 years, the earlier the BMI started to rise again. The mean protein content was $16 \%$ and the animal/vegetable protein ratio was approximately 3 (Deheeger et al. 1991). The recommended percentage is $12 \%$ for protein and 1 for the animal/vegetable protein ratio (WHO, 1985), so that protein intake in the 'low protein' group corresponded to normal intake, while it was excessive in the other two groups.

The influence of protein intake has also been evaluated by comparing breast fed children and infants during weaning who were given isocaloric formulae with high and low protein contents (Axelsson et al. 1988). Infants from the low protein group grew more like breast fed infants, who usually grow more slowly and have less body fat than formula fed infants (Fomon, 1974). Breast feeding is considered best for infants both during the suckling period and for the optimal development and health status of the child after weaning.

The use of low fat milk or a low carbohydrate formula also increases the protein intake. This could be one of the reasons for the increased prevalence of obesity (Rolland-Cachera, 1995) among children and adolescents even in the industrially developed countries who are also characterized by a low level of physical activity and exercise (Pařízková, 1996a).

Rolland-Cachera (1995) described the effect of a high protein intake early in life in relation to hormonal status in two contrasting situations. One corresponds to high energy needs (fasting state or low protein intake, exercise, cold, etc.) where insulin-like growth factor is low, growth hormone is high and insulin is low. The second corresponds to low energy needs (high protein 
and energy intake, sedentary lifestyle, warmth etc.) where insulin-like growth factor is high, growth hormone is low and insulin is high. The second variant may be the predisposing factor for early BMI rebound and later obesity (Rolland-Cachera,1995), and may also be related to the development of spontaneous physical activity. Significant relationships between activity and fatness were found in infants (Rose \& Mayer, 1968), and also in preschool children (Pařizková, 1977; Davies et al. 1995b).

The observation on the relation of BMI to protein intake after birth in infants and children agrees with the conclusions from experiments with animals given restricted amounts of energy and protein early in life (REP active). Also the comparison of BMI, intake of protein, prevalence of obesity in e.g. French and Czech children and adults indicates the importance of early diet, development of fatness and health risks in these populations (Pařízková \& RollandCachera, 1997). "Has malnutrition only bad consequences? What is the definition of health?" were the questions asked by Fanconi (1969) indicating that 'malnutrition' and its influence has to be be specified more exactly. Obviously, the effect depends on the degree of restriction as compared with the actual recommended dietary allowances (RDA) which have been considered higher than the real needs of the growing organism (Prentice et al. 1988). However, this coincidental evidence must be interpreted carefully and validated by further long term studies in humans.

\section{Functional characteristics and energy output in children}

The acceleration of somatic development and increase of body size in recent years does not necessarily run parallel with a corresponding acceleration of functional capacity, especially that of the cardiovascular system. This may be related to the generally decreased level of physical activity and exercise (Durnin et al. 1974; Durnin 1984; Nicklas et al. 1993; Schlicker et al. 1994; Pařizková \& Douglas, 1995). The BMI of Czech children measured in 1895 (Matiegka, 1929) and again in 1988 (Hajnis, 1993) showed a marked increase. Repeated measurements in the industrially developed countries do not show significant improvement of physical fitness in the average normal population, although there is increasing performance among small groups of top athletes at an international level (Pařizková, 1989b, 1995). Any benefit that might be seen to accrue from increasing body size has been compromised by the finding that body size and fatness increase relatively more than functional capacity and physical fitness (Pařizková, 1977; Prentice et al. 1988; Rolland-Cachera, 1995). However, data on the growth of individual systems and organs in normal healthy children are not available. It is not known for instance whether the heart and/or the whole cardiovascular system, neuromuscular system, or other systems or organs increase at the same rate as the total and/or lean body mass of a healthy child.

The comparison of aerobic power (evaluated as oxygen consumption during a maximal work load related to body weight, i.e. $\max \mathrm{O}_{2}$. $\mathrm{kg}_{\text {body weight }}{ }^{-1}$ ) of Russian children after World War II and in the seventies showed an increase of body size but a slight decline in aerobic power, indicating a lower level of cardiorespiratory fitness, in spite of the poorer diet of children during and after the war (Guminskyi et al. 1972); this was true of both energy and individual nutrients of food, especially proteins.

The adoption of a Western lifestyle and diet has not had an entirely beneficial effect on the development of Inuit children in Canada. A comparison of body size, body composition and physical fitness over a certain period of time after changing lifestyle and diet showed increased body size and fatness, but a decline in the level of functional capacity, namely the aerobic power which characterizes the level of cardiorespiratory fitness (Shephard, 1991). This may be 
relevant to the predisposition to diseases of civilization, particularly those of the cardiovascular system, and of diabetes (Pařízková 1987, 1993, 1994a,b). Comparison of smaller and leaner with bigger and fatter preadolescent boys in Tunisia showed a higher level of functional capacity (especially of the cardiorespiratory system) in smaller children with a lower food intake (Pařízková, 1977). Measurements of children in Mozambique resulted in similar conclusions (Prista et al. 1996). In South Africa, studies were made of the maximum oxygen consumption ( $\mathrm{ml} \mathrm{kg}^{-1} \mathrm{~min}^{-1}$ ) as reflected by performance of a 12 min walk-run. Mean values of $\mathrm{VO}_{2} \mathrm{~kg}^{-1}$ for rural African pupils, a third of whom were under the 5th centile of weight-forage, were closely similar to those of white children of the same age. Subsequent studies revealed lower mean values, although not significantly so, in pupils below the 5 th centile (Walker, 1995).

Measurements in the UK showed that food intake had decreased in recent years while body size and fatness had increased, which was explained mainly by a decrease of physical activity of children and adolescents (Durnin et al. 1974; Durnin, 1984). Inactivity has been considered one of the most important causes of the increase of obesity prevalence in US children (Gortmaker et al. 1990; Rippe et al. 1991) and also of risk factors already apparent in childhood and adolescence (Bogalusa heart study: Newman et al. 1986; Myers et al. 1995).

It has been suggested that RDA for children and adolescents should be reduced in order to regulate positive energy balance (Prentice et al. 1988). However, this does not seem to be a satisfactory solution because a reduction in food intake can cause an increased risk of deficiencies of various nutrients, especially vitamins and minerals. With a smaller food intake it is always more difficult to be sure that the intake of all nutrients reaches RDA.

The reduction in food intake is especially undesirable in children of preschool age when the level of spontaneous physical activity is very high, and, when a reduction goes against the natural tendencies of the development of the child. Measurements of energy expenditure with doubly labelled water in children 1.5-4.5 years of age have shown a mean energy expenditure of $4773 \mathrm{~kJ} / \mathrm{d}$ (Davies et al. 1994, 1995a). The value for energy output of children 1.5-2.49 years was $4472 \mathrm{~kJ} / \mathrm{d}$, and for children $3.5-4.49$ years was $5380 \mathrm{~kJ} / \mathrm{d}$. Energy intake was calculated following a $4 \mathrm{~d}$ weighed food record completed by the mother or guardian of the child. Measurements of energy intake and output were very close.

Estimated average daily energy intakes and requirements given by the WHO (1985) for boys $1-2$ and 4-5 years old are 5.02-7.07 MJ and for girls of similar ages $4.56-6.12 \mathrm{MJ} / \mathrm{d}$. The values given by WHO are approximately $10-30 \%$ higher than the values for energy output as assessed by the doubly labelled water, which corresponded to the values for energy intake measured in the same children (Davies et al. 1995a). This difference could be caused by a lower energy output in present day children, as compared with children some decades ago (Durnin, 1984). Secular changes in habitual physical activity may be responsible for reduced levels of motor activity and energy output (Davies et al. 1995b). Prentice et al. (1988) showed that children with an energy intake $\sim 10 \%$ lower than the RDA for energy grew normally.

\section{Genetic factors in spontaneous physical activity and fitness in early life}

The preschool period is sometimes described as a 'golden age' of children's motor development. Under physiological conditions, the level of physical activity of healthy children is high, but decreases when the child enters primary school. Longitudinal measurements of spontaneous physical activity with the help of pedometers showed that children are much more spontaneously active during the preschool years than during the first year of primary school. This is 
related not only to a changed mode of life at school but also to the fact that physical activity is also lower during later periods of the day, and during weekends (Pařizková \& Hainer, 1990). This seems to be a characteristic of this age period and might be a part of the child's maturation.

'Motor individuality' varies in a similar way to 'nutritional individuality' (Widdowson, 1962a, 1983, 1991; Pař́zková, 1977, 1996a,b), and there may be a close relationship between them. The amount of energy consumed and spent and its turnover varies among growing individuals (Pařízková, 1996b).

The level of spontaneous motor activity depends on genetic factors. Measurements of the amount of physical activity over 24-hour cycles showed greater similarity in monozygotic than in dizygotic twins (Ledovskaya, 1972). The level of physical activity was stable over a given period of time in healthy normal children. Days with a higher level of spontaneous physical activity alternated with days in which the activity level was lower. The resulting value for 1 week was a relatively stable characteristic for a particular child.

Measurements of energy expenditure in children 4-5 years of age with obese and nonobese parents showed lower values for resting and total energy output in children of obese parents. The energy expenditure for estimated physical activity of children of obese parents was about half the amount of energy for physical activity of children of nonobese parents (Griffiths \& Payne, 1976). This could be caused by both genetic factors and lifestyle of the families of the groups compared.

The pattern of motor stereotype in mutual relationships when performing a certain motor task is also genetically conditioned. This was followed by Sklad (1972) in monozygotic and dizygotic twins using a film recording method. The biomechanical stereotype of jumping, running etc. was more alike in monozygotic than in dizygotic twins or normal siblings of different age, or nonrelated children of the same age. It is also a general experience that gait, mimicking etc. is more similar in monozygotic twins than in unrelated children, and thus can help to identify them.

A high level of spontaneous physical activity of children of preschool age paralleled a trend for larger body size, less depot fat, higher level of cardiorespiratory performance and a higher food intake. Active children, 4.5 years old, were also characterized by significantly higher serum high density lipoproteins (see Fig. 2; Pařízková et al. 1986a,b; Pařízková, 1996a). Moreover, a higher level of activity was accompanied by other positive characteristics in spite of the higher food intake.

Inactive children deposited more fat, assessed by five skinfolds, than active children in the Bogalusa heart study as assessed by accelerometers (Moore et al. 1995). Both genetic and lifestyle factors appear to be involved as causes of these characteristic features of active and inactive children.

\section{The development of function as related to body composition and diet in young children}

There are relatively fewer data on the functional development of preschool children compared with that of school children. Extensive measurements were made in preschool children 3-6 years of age by Pařízková et al. (1983) and Pařízková (1977, 1996a,b). Along with the measurements of anthropometric variables, skinfolds and fat pattern, body composition and somatotypes, cardiorespiratory fitness, gross and fine motor development, muscle strength and body posture were also evaluated in repeated cross-sectional and longitudinal studies. Larger, representative and/or smaller samples of kindergarten children were measured. Dietary intake 


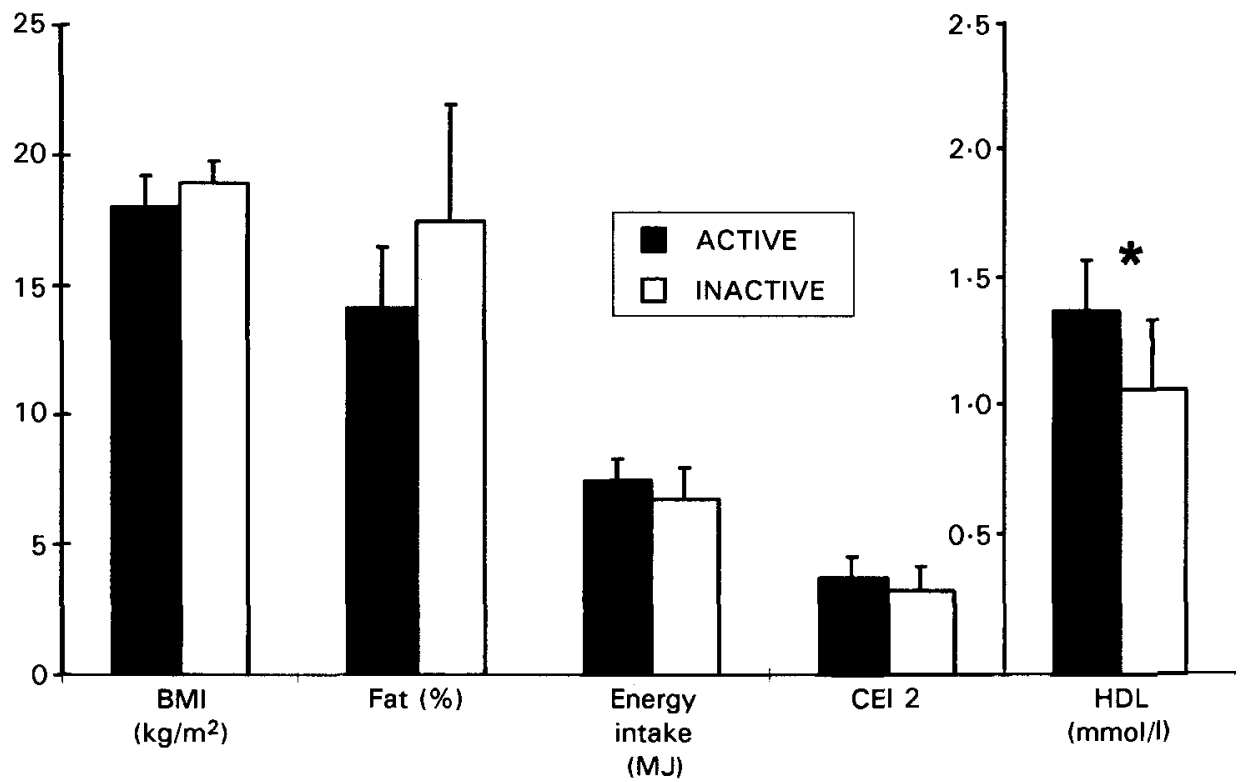

Figure 2. Body mass index, depot fat, energy intake, cardiac efficiency index (CEI 2) and high density lipoprotein serum level in active and inactive preschool children (Pařizková et al. 1982) (CEI $2=\mathrm{kpm} / \mathrm{HRwr}-10 \times \mathrm{HRr} ; \mathrm{kpm}=$ body weight $\times$ height of the step $\times 150$; $\mathrm{HRwr}=$ heart rate during $5 \mathrm{~min}$ work load, i.e.mounting the step and 3 mins of recovery, $\mathrm{HR} \mathrm{r}=$ heart rate at rest; $150=30$ mounts during $5 \mathrm{~min}$ ).

and serum lipids were also followed up in smaller groups; nine cross-sectional and three longitudinal studies were made in the seventies and eighties (Pařízková 1977, 1991, 1994a, 1996a,b; Pařízková et al. 1977, 1983; Pařízková \& Kábele, 1985, 1988).

Standard values for physical fitness, derived from the results of individual motor tests in the age categories from 3 to 7 years were established and used in teaching practice for the evaluation of the level of functional and motor development of children (Table 1). These data have also been used for the selection of children with retarded or advanced development, and have served as guidelines for interventions. In some studies the effect of environmental conditions, economic factors, family size and situation, diet and/or induced exercise were also followed (Pařízková et al.1983; Pařízková, 1996a).

The proportionality of the child's body evaluated by various indices relating length and breadth measures (Pařízková \& Adamec, 1980; Pařízková et al. 1983; Pařízková, 1996a) changed markedly from 3 to 7 years. Subcutaneous fat measured as skinfolds was the only variable which decreased in boys and remained constant in girls and this might also be related to a high level of spontaneous physical activity. Somatotype and fat distribution did not change significantly from 3 to 7 years. Body posture deteriorated during this period in Czech children, that is even before they entered the primary school. There was a slight but significant sex linked difference in body size (larger in boys including the breadth measurements of the skeleton) and fatness (greater in girls; Pařízková, 1978c; Pařízková et al. 1983, 1995; Pařízková, 1996a).

Gross motor performance increased with age as tested by summing up at speed $(20 \mathrm{~m}$ dash), endurance ( $500 \mathrm{~m}$ run) and muscle strength; performance was always higher in boys than girls. Tests of strength and coordination of lower and upper extremities (long jump, throwing) also gave higher results in boys (Table 1). Tests of fine motor development often showed a 
Table 1. Body mass index, sum of five skinfolds (Harpenden caliper), cardiac efficiency index CEI $2\left(^{*}\right)$, results of $20 \mathrm{~m}$ dash, long jump and ball throw with right hand in children 3-7 years of age

\begin{tabular}{|c|c|c|c|c|c|c|c|c|c|}
\hline \multirow[t]{2}{*}{ Age (years) } & & \multicolumn{2}{|l|}{$3-4$} & \multicolumn{2}{|l|}{$4-5$} & \multicolumn{2}{|l|}{$5-6$} & \multicolumn{2}{|l|}{$6-7$} \\
\hline & & $\bar{x}$ & SD & $\bar{x}$ & SD & $\bar{x}$ & SD & $\bar{x}$ & SD \\
\hline $\mathrm{BMI}\left(\mathrm{kg} / \mathrm{m}^{2}\right)$ & $\begin{array}{l}\text { boys } \\
\text { girls }\end{array}$ & $\begin{array}{l}15.38 \\
15.75\end{array}$ & $\begin{array}{l}1.2 \\
0.9\end{array}$ & $\begin{array}{l}17.59 \\
17.02\end{array}$ & $\begin{array}{l}1.3 \\
0.8\end{array}$ & $\begin{array}{l}18.37 \\
17.42\end{array}$ & $\begin{array}{l}0.9 \\
1.2\end{array}$ & $\begin{array}{r}18.54 \\
18.2\end{array}$ & $\begin{array}{l}1.3 \\
1.4\end{array}$ \\
\hline \multirow[t]{2}{*}{ Sum of 5 skinfolds $(\mathrm{mm})$} & boys & 29.2 & 8.7 & 26.6 & 4.4 & 26.6 & 7 & 20.9 & 3.7 \\
\hline & girls & 31.8 & 9 & 30.3 & 6.7 & 25.7 & 6.7 & 29.1 & 9.6 \\
\hline \multirow[t]{2}{*}{ CEI 2 (") $^{*}$} & boys & 3.12 & $1 \cdot 18$ & 2.95 & 1.19 & 3.45 & 0.92 & 3.68 & 0.82 \\
\hline & girls & 2.86 & 0.72 & 2.56 & 0.64 & 3.06 & 0.97 & $3 \cdot 18$ & 0.74 \\
\hline \multirow[t]{2}{*}{$20 \mathrm{~m}$ dash $(\mathrm{s})$} & boys & 6.8 & 0.8 & 6 & 0.8 & $5 \cdot 1$ & 0.2 & 4.9 & 0.2 \\
\hline & girls & 7.4 & 0.8 & $6 \cdot 2$ & 0.7 & 5.1 & 0.2 & $5 \cdot 1$ & 0.3 \\
\hline \multirow[t]{2}{*}{ Long jump (cm) } & boys & 60.7 & 15.4 & 75.5 & 12.8 & 95.9 & 14.4 & 103.5 & 18.7 \\
\hline & girls & 59.1 & 18.6 & 71.6 & $15 \cdot 7$ & 90.9 & 17.7 & 96.2 & 16.5 \\
\hline \multirow[t]{2}{*}{ Ball throw $-r$. hand $(\mathrm{cm})$} & boys & 419 & 142 & 562 & 199 & 813 & 209 & 1028 & 404 \\
\hline & girls & 326 & 101 & 438 & 131 & 601 & 126 & 695 & 135 \\
\hline
\end{tabular}

higher performance in girls (sensomotor tests) as well as tests of orientation in space and laterality (Pařízková, 1977, 1991, 1994a, 1996a ; Pařízková et al. 1983; Pařízková, unpublished data).

Children born with a higher birth weight remained heavier at 4-6 years of age. As regards motor development, only throwing with the left hand and in certain cases balance tests sometimes scored higher in children born and remaining heavier (Pařízková, 1994b).

\section{The effect of regular exercise in young children}

Children participating in regular exercise specially tailored for this age group, for example, organized in groups for the child with mother or father and/or one of the grandparents, had a significantly larger body size and scored better in selected motor performance tests by the time they reached 6 years, and only occasionally earlier. Measurements on smaller samples showed less depot fat in children adapted to exercise (Pařízková, 1977, 1996a).

A cross-sectional study has been made in the UK on preschool children 1.5-4.5 years old, which included exact measurements of physical activity and energy output (Davies et al. $1995 a, b)$. Physical activity was assessed as the ratio of total energy expenditure (TEE)/BMR and TEE minus BMR. TEE was measured by the doubly labelled water technique, and BMR was predicted from body weight. Body fat content was assessed from measurements of total body water by stable isotope dilution. Those who were more physically active contained less fat (r $=-0.52, P<0.001)$.

Body composition and motor development depend on lifestyle and physical activity, starting soon after birth. Higher levels of physical performance were found in 4-6 year old children participating in special recreational physical education with one of the parents (Paŕízková, 1996a). In preschool children there was a significant correlation between depot fat and serum level of total cholesterol $(\mathrm{r}=0.488,0.02>P>0.01)$, and depot fat and serum level of triacylgycerols $(\mathrm{r}=0.494,0.02>P>0.01$; Pařízková, 1989, 1996a). Lower deposition of fat is therefore favourable from the point of view of obesity prevention (Davies \& Christoffel, 1994), reduction of the level of serum lipids as well as later cardiovascular risk. All factors leading to a lower deposition of fat are recommended including suitable exercise and diet with adequate protein. 


\section{Summary, conclusions and perspectives}

Physical activity and exercise, which are closely related to food intake and composition of the diet, have a significant influence on growth, the development of tissues and organs and on metabolism, especially in early life. Until now, the effect of diet during growth was most often evaluated without simultaneous assessment of energy output, which involves measurements of physical activity. A high level of spontaneous motor activity is one of the characteristics of an animal during growth after birth, and contributes to the high level of energy turnover during this period of life. Measurements in experimental animals (rats) as well as humans confirmed this.

The level of spontaneous motor activity varies among individuals, and can be increased by a marginally decreased (but not extreme) dietary intake with a smaller amount of proteins in infancy. As shown in experimental models, this is accompanied later in life by significant changes in a number of metabolic characteristics concerning lipids, body composition, rate and economy of growth and adult body size. Under such conditions, the cardiac muscle is more resistant to noxious factors (such as isoprenaline) that cause experimental cardiac necrosis in laboratory animals. The same features are also found in a growing or young animal.

Delayed effects of exercise during pregnancy in rats can be seen in the adult offspring. There are positive changes of cardiac microstructure, increased cardiac resistance to isoprenaline along with several aspects of lipid metabolism.

Exercise trained mothers who continued endurance exercise during pregnancy had smaller and leaner infants at birth than those of unexercised mothers; later consequences have not yet been followed. The effect of chronic and current exercise of the mother, both during the period before pregnancy as well as during pregnancy, requires further study.

The level of physical activity, cardiorespiratory fitness, gross and fine motor development, body composition, dietary intake, and blood lipids in young children undergo significant changes in early life. Standards for Czech children of preschool age which were not available before have been established; they enable us to evaluate the level of development and also render possible the necessary interventions in diet and physical activity regimens, assuring a desirable optimal development of the child. Measurements during recent decades indicate that the general level of fitness, especially of the cardiorespiratory system, has not developed at the same pace as body size, and on average thus has relatively deteriorated. On the other hand, the BMI and fatness have increased, and there is a higher prevalence of obesity during growth and adolescence mainly due to low activity since birth.

Longitudinal studies of BMI and fatness in French children showed that a higher intake of proteins early in life facilitated an early rebound of BMI and promoted the development of obesity later, which is a risk factor for cardiovascular diseases. Comparison of changes in BMI during development in different populations shows coincidental evidence on possible relationships between higher intake of proteins during the first years of life, earlier increase of BMI and later obesity, poorer health (especially higher morbidity and mortality due to cardiovascular diseases) and shorter life span. Data on long living populations in the Caucasus also showed slower growth, smaller body size, greater leanness and higher physical activity in adulthood.

This information suggests that greater attention to protein and energy intakes and physical activity by pregnant mothers and their children may be beneficial for long term health as well as being economically advantageous. Such recommendations may imply a return to a situation that existed not so long ago when conditions allowed better self regulation of both physical activity and food choice and can be expected to improve cardiorespiratory fitness, gross and 
fine motor function and body posture, prevent excessive fat deposition and reduce serum lipid concentrations. More long term studies covering the prenatal and early postnatal period of growth, and focusing on consequences later in life are necessary for the elucidation of the effect of the interactions between diet and exercise. Wider use of simple but reliable methods for the evaluation of the level of physical activity and fitness in young children is also a target for this purpose.

\section{References}

Alberti-Fidanza, A., Pařízková, J. \& Fruttini, D. (1995). Relationship between mothers' and newborns' nutritional and blood lipid variables. European Journal of Clinical Nutrition 49, 289-298.

Anon. (1994). Exercise during pregnancy and the postpartum period (ACOG Technical Bulletin no. 189). International Journal of Gynaecology \& Obstetrics 45, 65-70.

Arshavskyi, I.A. (1967). [Developmental physiology.] Moscow: Medicina.

Avery, M.D., Leon, A.S. \& Kopher, R.A. (1997). Effects of a partially home-based exercise program for women with gestational diabetes. Obstetrics \& Gynecology 89, 10-15.

Axelsson, I.E., Jakobsson, I. \& Räihä, N.C.R. (1988). Formula with reduced protein content: effects on growth and protein metabolism during weaning. Pediatric Research 24, 297-301.

Barker, D.J.P. (1990). The fetal and infant origins of adult diseases. British Medical Journal 301, 111.

Barker, D.J.P. (1994). Mothers, Babies, and Disease in Later Life. London: BMJ Publishing Group.

Bell, R. \& O'Neill, M. (1994). Exercise and pregnancy: a review. Birth 21, 85-95.

Botkin, C. \& Driscoll, C.E. (1991). Maternal aerobic exercise: newborn effects. Family Practice Research Journal 11, 387-393.

Clapp, J.F. (1991). Exercise and fetal health. Journal of Developmental Physiology 15, 9-14.

Clapp, J.F. (1996). Morphometric and neurodevelopmental outcome at age five years of the offspring of women who continued to exercise regularly. Journal of Pediatrics 129, 856-863.

Clapp, J.F. \& Capeless, E.L. (1990). Neonatal morphometrics after maternal endurance exercise during pregnancy. Americal Journal of Obstetrics \& Gynecology 163, 1805-1811.

Cobrin, M. \& Koski, K.G. (1995). Maternal dietary carbohydrate restriction and mild-to-moderate exercise during pregnancy modify aspects of fetal development in rats. Journal of Nutrition 125, 1617-1627.

Courant, G.T. \& Barr, S.I. (1990). Exercise during rat pregnancy and lactation: matemal effects and offspring growth. Physiology \& Behavior 47, 427-433.

Dale, E., Mullinax, K.M. \& Bryan, D.H. (1982). Exercise during pregnancy: effects on the fetus. Canadian Journal of Applied Sports Sciences 7, 98-103.

Davies, P.S.W., Coward, W.A., Gregory, J., White, A. \& Mills, A. (1994). Total energy expenditure and energy intake in the pre-school child: a comparison. British Journal of Nutrition 72, 13-20.

Davies, P.S.W., Gregory, J. \& White, A. (1995a). Energy expenditure in children 1.5 to 4.5 years: a comparison with current recommendation for energy intake. European Journal of Clinical Nutrition 49, 360-364.

Davies, P.S.W., Gregory, J. \& White, A. (1995b). Physical activity and body fatness in preschool children. International Journal of Obesity 19, 6-10.

Davies, S.W. \& Christoffel, K.K. (1994). Obesity in preschool-age children. Treatment early and often may be best. Archives of Pediatric and Adolescent Medicine 148, 1257-1261.

Deheeger, M., Rolland-Cachera, M.-F., Péquignot, F., Labadie, M.D., Rossignol, C. \& Vinit, F. (1991). [Food intake changes of French children two years old between 1973 and 1986]. Annals of Nutrition and Metabolism 35, 132-140.

Denadai, B.S., Piçarro, I. da C., Madjian, S., Bergamaschi, C.T., Santos, V.C., da Silva, A.C. \& Russo, A.K. (1994). High intensity exercise during pregnancy of rats. Effects on mother and offspring. Comparative Biochemistry \& Physiology, A. Comparative Physiology 109, 727-740.

Durnin, J.V.G.A. (1984). Energy balance in childhood and adolescence. Proceedings of the Nutrition Society 43, $271-$ 279.

Durnin, J.V.G.A., Lonergan, M.E., Good, J. \& Ewan, A. (1974). A cross-sectional nutritional and anthropometric study with an interval of 7 years on 611 young adolescent schoolchildren. British Journal of Nutrition 32, 169-179.

Faltová, E., Mráz, M., Pařízková, J. \& Šedivý, J. (1985). Physical activity of different intensities and the development of myocardial resistence to injury. Physiologia Bohemoslovaca 34, 289-296.

Faltová, E. \& Pařízková, J. (1970). Effect of age, body weight and body fat on experimental cardiac necrosis. Physiologia Bohemoslovaca 19, 275-280.

Faltová, E., Pařizková, J., Mráz, M., Šedivý, J. \& Špátová, M. (1983). Influence of motor activity on the development of isoprenaline induced heart lesions. Physiologia Bohemoslovaca 32, 203-209.

Fanconi, G. (1969). Has malnutrition only bad consequences? What is the definition of health? In Protein and Energy Malnutrition, pp. 57-62 [A. von Muralt, editor]. Berlin: Springer-Verlag. 
Fomo̊n, S.J. (1974). Effect of mode of feeding and dietary composition on growth and body composition during early infancy. Infant Nutrition, 2nd edn, pp. 77-79. Philadelphia, PA: Saunders.

Gortmaker, S.L., Dietz, W.H. \& Cheung, L.W.Y. (1990). Inactivity, diet, and the fattening of America. Journal of the American Dietetic Association 90, 1247-1252.

Griffiths, M. \& Payne, P.R. (1976). Energy expenditure in small children of obese and non-obese parents, Nature 260, 698-700.

Guminskyi, A.A., Elizarova, O.S., Zhurkova, N.N., Zolotayko, G.A., \& Novozhilova, A.D. (1972). [On functional acceleration of present day youth.] Pediatryia no. 3, 10-18.

Hajnis, K. (1993). [New development norms for Czech and Slovak children and adolescents.] Anthropologischer Anzeiger 51, 207-224.

Hall, D.C. \& Kaufmann, D.A. (1987). Effects of aerobic exercise and strength conditioning on pregnancy outcomes. Americal Joumal of Obstetrics \& Gynecology 157, 1199-1203.

Himmelmann, A., Svensson, A., Sigstrom, L. \& Hansson, L. (1994). Predictors of blood pressure and left ventricular mass in the young: the Hypertension in Pregnancy Offspring Study. American Journal of Hypertension 7, 381-389.

Honda, M., Lowy, C. \& Thomas, C.R. (1990). The effect of matemal diabetes on placental transfer of essential and nonessential fatty acids in the rat. Diabetes Research 15, 47-51.

Jackson, A. (1992). How can early diet influence later disease? In Tomorrow's Nutrition, pp. 23-30 [M. Ashwell, editor]. BNF Nutrition Bulletin 17 (Suppl.).

Kraut, H. (1972). Food intake as a factor of production. In Alimentation et Travail, Premier Symposium International, pp. 216-225 [G. Debry \& R. Bleyer, editors]. Paris: Masson et Cie.

Ledovskaya, N.M. (1972). [Experiences in the assessment of physical activity in twins.] In [Physical Activity in Man and Hypokinesia], pp. 30-36 [A.D. Slonim \& K.M. Smirnov, editors]. Novosibirsk: Academy of Sciences of USSR, Siberian Dept., Institute of Physiology.

Lookey, E.A., Tran, Z.V., Wells, C.L., Myers, B.C. \& Tran, A.C. (1991). Effects of physical exercise on pregnancy outcomes: a meta-analytic review. Medicine \& Science of Sports \& Exercise 23, 1234-1239.

McCance, R.A., \& Widdowson, E.M. (1974). The determinants of growth and form. Review lecture. Proceedings of the Royal Society of London, B. Biological Sciences 185, 1-17.

McCay, C.M., Maynard, L.A., Sperling, G. \& Barnes, L.L. (1939). Retarded growth span, ultimate body size and age changes in the albino rat after feeding diets restricted in calories. Journal of Nutrition 18, 1-13.

McCay, C.M., Sperling, G. \& Barnes, L.L. (1941). Growth, ageing, chronic diseases, and life span in rats. Archives of Biochemistry 2, 469-479.

Macho, L., Štrbák, V. \& Hromadová, A.M. (1973). Effect of early undernutrition and overnutrition on thyroid gland function in rats. Endocrinologia 62, 94-99.

Masoro, E.J. (1992). Retardation of aging process by nutritional means. Annals of the New York Academy of Sciences 673, 29-35.

Masoro, E.J. (1993). Dietary restriction and aging. Journal of the American Geriatrics Society 41, 994-999.

Masoro, E.J. (1995) Antiaging action of caloric restriction: endocrine and metabolic aspects. Obesity Research 2 (Suppl.3), 241s-247s.

Masoro, E.J. (1996). McCay's hypothesis: undernutrition and longevity. Proceedings of the Nutrition Society 54, 657664.

Matiegka, J. (1929). [Somatology of school children.] Prague: Czechoslovak Academy of Sciences and Arts (CAVU).

Miklashevskaya, N. (1994). Growth process of children and adolescents of the longevity populations. In Growth and Development of Man IV, pp. 175-179 [K. Hajnis, editor]. Prague: Department of Anthropology, Charles University, and Czechoslovak Association of Anthropology.

Moore, L.L., Nguyen, U.-S. D.T., Rothman, K.J., Cupples, L.A. \& Ellison, R.C. (1995). Preschool physical activity level and changes in body fatness in young children. The Framingham children's study. American Joumal of Epidemiology 142, 982-988.

Myers, L., Coughlin, S.S., Webber, L.S., Srinivasan, S.R. \& Berenson, G.S. (1995). Prediction of adult cardiovascular multifactorial factor risk status from childhood risk factor levels. The Bogalusa Heart Study. American Journal of Epidemiology 142, 918-924.

Newman, W.P., Freedman, D.S., Voors, A.W., Gard, P.D., Srinivasan, S.R., Cresanta, J.L., Williamson, G.D., Webber, L.S. \& Berenson, G.S. (1986). Relation of serum lipoprotein levels and systolic blood pressure in early atherosclerosis: the Bogalusa Heart Study. New England Journal of Medicine 314, 138-144.

Nicklas, T.A., Webber, L.S., Srinivasan, S.R. \& Berenson, G.S. (1993). Secular trends in dietary intakes and cardiovascular risk factors of 10-y-old children: The Bogalusa Heart Study (1973-1988). American Journal of Clinical Nutrition 57, 930-937.

Pařizková, J. (1963a). Age trends in fatness in normal and obese children. Journal of Applied Physiology 16, 1734 1735.

Pařizková, J. (1963b). The impact of age, diet and exercise on man's body composition. Annals of the New York Academy of Sciences 110, 661-674.

Paŕizková, J. (1975). Impact of daily work load during pregnancy on the microstructure of the rat heart in male offspring. European Joumal of Applied Physiology and Occupational Physiology 34, 323-328.

Pařizková, J. (1977). Body Fat and Physical Fitness. Body Composition and Lipid Metabolism in Different Regimes of Physical Activity. The Hague: Martinus Nijhoff B.V. I Medical Division. 
Pařizková, J. (1978a). The impact of daily work load during pregnancy and/or postnatal life on heart microstructure of rat male offspring. Basic Research in Cardiology 73, 433-441.

Pařízková, J. (1978b). Body composition and lipid metabolism in relation to nutrition and exercise. In Nutrition, Physical Fitness and Health (International Series of Sports Sciences vol. ), pp. 61-75. [J. Paříková and V.A. Rogozkin, editors]. Baltimore, MD: University Park Press.

Parízková, J. (1978c). The impact of ecological factors and physical activity on the somatic and motor develoment of preschool children. In Physical Fitness Assessment. Principles, Practice and Application, pp. 238-247 [R.J. Shephard and H. Lavallée, editors]. Springfield, IL: Charles C.Thomas.

Pař́zková, J. (1979). Cardiac microstructure in female and male offspring of exercised rat mothers. Acta Anatomica 104, 382-387.

Pař́zková, J. (1987). Growth, functional capacity and physical fitness in normal and malnourished children. World Review of Nutrition \& Dietetics 51, 1-44.

Pařizková, J. (1989a). Age-dependent changes in dietary intake related to work output, physical fitness, and body composition. American Joumal of Clinical Nutrition 49, 962-967.

Pař́zková, J. (1989b). Nutritional individuality and physical performance in different periods of life. In International Perspectives in Exercise Physiology, pp. 104-114 [K. Nazar, R.L. Terjung, H. Kaciuba-Uscilko and L. Budohoski, editors]. Champaign, IL: Human Kinetics Books.

Pařizková, J. (1991). Human growth, physical fitness and nutrition under various environmental conditions. In Human Growth, Physical Fitness and Nutrition (Medicine and Sports Science vol. 31), pp. 1-18 [R.J. Shephard \& J. Pařízková, editors]. Basel: Karger.

Pařízková, J. (1993). Food choices in Czechoslovakia. Appetite 21, 299-302.

Pařízková, J. (1994a). Nutrition and physical performance during growth. In Nutrition in a Sustainable Environment (Proceedings of the XV International Congress of Nutrition), pp. 463-465. [M.L.Wahlquist, A.S. Truswell, R. Smith and P. Nestel, editors]. London: Smith-Gordon/Nishimura.

Pařizková, J. (1994b). Relationship of nutritional status and functional development in preschool age children. In Nutrition in Pregnancy and Growth (Bibliotheca Nutritio et Dieta no. 53), pp. 109-115 [M. Porrini and P. Walter, editors]. Basel: Karger.

Pařzková, J. (1995). Changes in approach to the measurement of body composition. In Body Composition Techniques in Health and Disease, pp. 222-239. [P.S.W. Davies and T.J. Cole, editors]. Cambridge: Cambridge University Press.

Pař́zková, J. (1996a). Nutrition, Physical Activity and Health in Early Life. Boca Raton, FL: CRC Press.

Pařízková, J. (1996b). How much energy consumed and spent for optimal growth and development? Nutrition 12, 820821.

Pařizková, J. \& Adamec, A. (1980). Longitudinal study of anthropometric, skinfold, work and motor characteristics of boys and girls, three to six years of age. American Journal of Physical Anthropology 52, 387-396.

Pařizková, J., Adamec, A., Berdychová, J., Čermák, J., Horná, J. \& Teplý, Z. (1983). Growth, Fitness and Nutrition in Preschool Children. Prague: Charles University.

Pařízková, J., Čermák. J. \& Horná, J. (1977). Sex differences in somatic and functional characteristics of preschool children. Human Biology 49, 437-451.

Pařizková, J. \& Douglas, P.D., editors (1995). Human Growth, Dietary Intake and Other Environmental Influences (Proceedings of a Symposium; 13th International Congress of Anthropological and Ethnological Sciences, Mexico City, 1993). Paris: Danone.

Pařízková, J. \& Faltová, E. (1970). Physical activity, body fat and experimental cardiac necrosis. British Journal of Nutrition 24, 3-10.

Pařízková, J., Faltová, E., Mráz, M. \& Špátová, M. (1982). Growth, food intake, motor activity and experimental cardiac necrosis in early malnourished male rats. Annals of Nutrition \& Metabolism 26, 121-128.

Pařizková, J., Fraňková, S., Špátová, M. \& Petrásek, R. (1980). Spontaneous motor activity, energy cost of growth and lipid metabolism in the liver in male rats with early protein energy malnutrition. Baroda Journal of Nutrition 7, 4954.

Pařízková, J. \& Hainer, V. (1990). Exercise in growing and adult obese individuals. In Current Therapy in Sports Medicine, pp. 22-26 [J.S. Torg, R.P. Welsh and R.J. Shephard, editors]. Toronto: H.B.C. Decker Inc.

Pařizková, J., Hainer, V., Štich, V., Kunešová, M. \& Ksantini, M. (1995). Physiological capabilities of obese individuals and implications for exercise. In Exercise and Obesity, pp. 131-140 [M. Wahlquist \& A.P. Hills, editors]. London: Smith Gordon.

Pařízková, J. \& Kábele, J. (1985). [Somatic and psychological development, performance and fitness, body posture and food intake in the relationship to physical activity regime of preschool children.] Acta Universitatis Carolinae Gymnica 21, 55-69.

Pařízková, J. \& Kábele, J. (1988). Longitudinal study of somatic, motor and psychological development in preschool boys and girls. Collegium Anthropologicum 12, 67-73.

Pařízková, J., Macková, E., Kábele, J., Macková, J. \& Š̀kopková, M. (1986a). Body composition, food intake, cardiorespiratory fitness, blood lipids and psychological development in highly active and inactive preschool children. Human Biology 58, 261-273. 
Pařizková, J., Macková, E., Macková, J. \& Skopková, M. (1986b). Blood lipids as related to food intake, body composition, and cardiorespiratory efficiency in preschool children. Joumal of Pediatric Gastroenterology \& Nutrition 5, 295-298.

Pařizková, J. \& Petrásek, R. (1978). The impact of daily work load during pregnancy on lipid metabolism in the liver of the offspring. European Journal of Applied Physiology and Occupational Physiology 39, 81-87.

Pař́zková, J. \& Petrásek, R. (1979). Impact of early nutrition on later development of spontaneous physical activity and lipid metabolism. Nutrition \& Metabolism 23, 266-274.

Pařizková, J., Petrásek, R. \& Fraňková, S. (1979). The impact of reduced energy and protein intake at the beginning of life on growth, spontaneous motor activity and lipid metabolism in male rats. International Joumal of Nutrition \& Dietetics 16, 412-416.

Pařizková, J. \& Rolland-Cachera, M.-F. (1997). High protein early in life as a predisposition for later obesity and further health risks. Nutrition 13, 818-819.

Par̆izková, J. \& Staňková, L. (1964). Influence of physical activity on a treadmill on the metabolism of adipose tissue in rats. British Journal of Nutrition 18, 325-332.

Pař́zková, J., Wachtlová, M. \& Soukupová, M. (1972). The impact of different motor activity on body composition, density of capillaries and fibres in the heart and soleus muscles, and cell's migration in vitro in male rats. Internationale Zeitschrift für Angewandte Physiologie einschiesslich Arbeitsphysiologie 30, 207-216.

Perales, J.G., Patricio, F.R.S., Amancio, O.M.S., Piçarro, I.C., Rodrigues, L.O.C. \& Russo, A.K. (1992). Effects of exercise and food restriction in pregnant and newborn rats. Pre-pregnancy maximum oxygen consumption. Comparative Biochemistry \& Physiology, A. Comparative Physiology 102, 585-590.

Piçarro, I.C., Barros Neto, T.L., Carrero DeTeves, D., Silva, A.C., Denadai, D.S., Tarasantchi, J. \& Russo, A.K. (1991). Effect of exercise during pregnancy, graded as a percentage of aerobic capacity. Maternal and fetal responses of the rat. Comparative Biochemistry \& Physiology, A. Comparative Physiology 100, 795-799.

Piçarro, I.C., Turecki, G.X., Barros-Neto, T.L., Russo, A.K., Silva, A.C. \& Tarasantchi, J. (1989). Effect of exercise training during pregnancy: maternal and fetal responses of the rat. Brazilian Joumal of Medical \& Biological Research 22, 1535-1538.

Prentice, A.M., Lucas, A., Vasquez-Velasquez, L., Davies, P.S.W. \& Whitehead, R.G. (1988). Are current dietary guidelines for young children a prescription for overfeeding? Lancet ii, 1066-1069.

Prista, A., Maia, J.A.R. \& Marques, A.T. (1996). Nutritional status and physical fitness of children and youth of Maputo: relevance of nutritional indicators. In Abstracts and Program, International Council for Physical Activity and Fitness Research, Symposium '96, p.58.

Rippe, J.M., Blair, S.N., Freedson, P., Micheli, L.J., Morrow, J.R., Pate, R., Plowman, J.M. \& Rowland, T. (1991). Childhood health and fitness in the United States: current status and future challenges. In Round Table Discussion at the American College of Sports Medicine, part I, pp. 97-104, and part II, pp. 171-181. Orlando, FL: Academic Press.

Robinson, J., Chidzanja, S., Kind, K., Lok, F., Owens, P. \& Owens, J. (1995). Placental control of fetal growth. Reproduction, Fertility \& Development 7, 333-344.

Rodgers, C.D., Mottola, M.F., Corbett, K. \& Taylor, A.W. (1991). Skeletal muscle metabolism in the offspring of trained rats. Journal of Sports Medicine \& Physical Fitness 31, 389-395.

Rolland-Cachera, M.-F. (1995). Prediction of adult body composition from infant and childhood measurements. In Body Composition Techniques in Health and Disease, pp. 100-145 [P.S.W. Davies and T.J. Cole, editors]. Cambridge: Cambridge University Press.

Rolland-Cachera, M.-F., Bellisle, F., Deheeger, M., Guilloud-Bataille, M., Péquignot, F. \& Sempé, M. (1988). Adiposity development and prediction during growth in humans: a two decade follow-up study. In Obesity in Europe 88, pp. 73-78 [P. Björntorp and S. Rössner, editors]. London: John Libbey.

Rolland-Cachera, M.-F., Deheeger, M., Bellisle, F., Sempé, M., Guilloud-Bataille, M. \& Patois, E. (1984). Adiposity rebound in children: a simple indicator for predicting obesity. American Journal of Clinical Nutrition 39, 129-135.

Rolland-Cachera, M.-F., Deheeger, M. \& Bellisle, F. (1995). Early nutrition and later outcomes. International Journal of Obesity 19 (Suppl.2), 11.

Rose, H.E. \& Mayer, J. (1968). Activity, calorie intake, fat storage, and the energy balance of infants. Pediatrics 41, 1829.

Ross, M.H. (1961). Length of life and nutrition in the rat. Journal of Nutrition 75, 197-210.

Ross, M.H. (1964). Nutrition, disease and length of life. In Diet and Bodily Constitution (CIBA Foundation, Study Group no. 17), pp. 90-107 [G.E.W. Wolstenholme and M. O'Connor, editors]. London: J. and A. Churchill.

Ross, M.H. (1972). Length of life and caloric intake. American Journal of Clinical Nutrition 25, 834-838.

Ross, M.H., Lustbader, E. \& Bras, G. (1976). Dietary practices and growth responses as predictors of longevity. Nature 262, 548-553.

Ruwe, P.J., Wolverton, C.K., White, M.E. \& Ramsay, T.G. (1991). Effect of maternal fasting on fetal and placental lipid metabolism in swine. Joumal of Animal Science 69, 1935-1944.

Schlicker, S.A., Borra, S.T. \& Regan, C. (1994). The weight and fitness status of United States children. Nutrition Reviews 52, $1 \mathrm{I}-17$.

Schramm, W.F., Stockbauer, J.W. \& Hoffman, H.J. (1996). Exercise, employment, other daily activities, and adverse pregnancy outcomes. American Journal of Epidemiology 143, 211-218. 
Shephard, R.J. (1991). Somatic growth and physical performance in Canada. In Human Growth, Physical Fithess and Nutrition (Medicine and Sports Science, vol. 31), pp. 133-155. [R.J. Shephard and J. Pař́zková, editors]. Basel: Karger.

Sklad, M. (1972). Similarity of movements in twins. Wychowanie Fizyczne i Sport 3, 119-132.

Smart, J.L. (1974) Activity and exploratory behavior of adult offspring of undernourished mother rats. Developmental Psychobiology 7, 315-321.

Spinnewijn, W.E.M., Lotgering, F.K., Struijk, P.C. \& Wallenburg, H.C.S. (1996). Fetal heart rate and uterine contractility during maternal exercise at term. American Journal of Obstetrics \& Gynecology 173, 43-48.

Stephenson, T.J., Stammers, J.P. \& Hull, D. (1991). Effects of altering umbilical flow and umbilical free fatty acid concentration on transfer of free fatty acids across the rabbit placenta. Joumal of Developmental Physiology 15, 221227.

Sternfeld, B., Quesenberry, C.P., Eskenazi, B. \& Newman L.A. (1995). Exercise during pregnancy and pregnancy outcome. Medicine \& Science in Sports \& Exercise 27, $634-640$.

Suzuki, S., Oshima, S., Tsuji, E., Tsuji,K. \& Ohto, F. (1978). Interrelationships between nutrition, physical activity, and physical fitness. In Nutrition, Physical Fitness and Health (International Series of Sports Sciences, vol. 7), pp. 194 214 [J. Pařízková and V.A. Rogozkin, editors]. Baltimore, MD: University Park Press.

Szabo, A.J., Oppermann, W., Hannover, B., Guggliucci, C. \& Szabo, O. (1975). Fetal adipose tissue development. Relationship to maternal free fatty acid levels. In Early Diabetes in Early Life, pp. 17-21 [R.A. Camerini-Davalos and H.S. Cole, editors]. New York: Academic Press.

Treadway, J.L. \& Lederman, S.A. (1986). The effects of exercise on milk yield, milk composition, and of spring growth in rats. American Journal of Clinical Nutrition 44, 481-488.

Uzendoski, A.M., Latin, R.W., Berg, K.E. \& Moshier, S. (1990). Physiological responses to aerobic exercise during pregnancy and post-partum. Journal of Sports Medicine \& Physical Fitness 30, 77-82.

Walker, A.R.P. (1995). Nutrition-related diseases in Southerm Africa: with special reference to urban African populations in transition. Nutrition Research 15, 1053-1094.

Waterlow, J.C. (1992). Protein and Energy Malnutrition. London: Edward Arnold.

Widdowson, E.M. (1962a). Nutritional individuality. Proceedings of the Nutrition Society 21, 121-128.

Widdowson, E.M. (1983). How much food does man require? An evaluation of human energy needs. In Nutritional Adequacy, Nutrient Availability and Needs (Nestlé Nutrition Research Symposium, 1982; Experientia Suppl. no. 44) pp. 11-25 [J. Mauron, editor]. Basel: Birkhäuser.

Widdowson, E.M. (1991). Contemporary human diets and their relation to health and growth: overview and conclusions. Philosophical Transactions of the Royal Society of London, B. Biological Sciences 334, 289-295.

Widdowson, E.M. \& Kennedy, G.C. (1962b). Rate of growth, mature weight and life-span. Proceedings of the Royal Society of London, B. Biological Sciences 156, 96-108.

Widdowson, E.M. \& McCance, R.A. (1960). Some effects accelerating growth. I. General somatic development. Proceedings of the Royal Society of London, B. Biological Sciences 152, 188-206.

Widdowson, E.M. \& McCance, R.A. (1963). The effect of finite periods of undernutrition at different ages on the composition and subsequent development of the rat. Proceedings of the Royal Society of. London, B. Biological Sciences 158, 329-342.

WHO (1985). Energy and Protein Requirements. Report of a Joint FAONWO/UNU Expert Consultation, FAO, Rome, 1981 (Technical Report Series no. 724). Geneva: World Health Organization.

Zhang, J. \& Savitz, D.A. (1996). Exercise during pregnancy in US women. Annals of Epidemiology 6, 53-59. 